DOI: 10.17707/AgricultForest.65.2.08

\author{
Ramyar ALIRAMAYEE, \\ Abdulvahed KHALEDI DARVISHAN, Mahmood ARABKHEDRI ${ }^{1}$
}

\title{
INVESTIGATING THE HYDROLOGICAL RESPONSE AND NUTRIENT LOSS IN RAINFED LANDS IN NORTHEAST OF IRAN USING RAINFALL SIMULATOR
}

\begin{abstract}
SUMMARY
Topsoil is the richest part in terms of the amount of organic matter and nutrients. Therefore, its lost is more harmful compared to the subsoil. During the erosion process, soil nutrients are either lost as dissolved or absorbed to the soil particles. The present study was aimed to investigate the effects of rainfall intensity and slope gradient on infiltration, runoff, soil and nutrients $(\mathrm{N}, \mathrm{P}, \mathrm{K})$ loss in rainfed lands of Pishkamar region, NE of Iran. To achieve the study purposes, four rainfall intensities of 33, 64, 80 and $110 \mathrm{~mm} \mathrm{~h}^{-1}$ were simulated using Kamphorst rainfall simulator in three slope gradients of 6, 12 and 25\%. Two slope aspects of north and south were also considered for the slope gradient of $25 \%$.

The results showed that the effects of rainfall intensity and slope gradient on infiltration and runoff were significant, while the effect of slope aspect (north and south) was not. Taking into account the linear trend, the plot hydrological response threshold of sediment concentration was about $50 \mathrm{~mm} \mathrm{~h}^{-1}$ of rainfall intensity and $9 \%$ of slope. In the case of total soil loss, however, higher thresholds were obtained for rainfall intensities (about $72 \mathrm{~mm} \mathrm{~h}^{-1}$ ) and slope gradients (about 18\%). The effect of rainfall intensity and slope gradient on soil loss were significant individually, but no interaction was observed among study factors. The results of nutrient losses showed considerable loss for Potassium in the runoff and Phosphorus and Potassium in the sediment.
\end{abstract}

Keywords: Average infiltration rate, Average runoff coefficient, Soil and sediment granulometry, Soil erosion, Soil fertility

\section{INTRODUCTION}

Soil erosion is one of the environmental treats to the ecosystem that leads to soil and water quality degradation and washes away the fertile topsoil and reduces agricultural production (Chalise et al., 2019). The natural and accelerated

\footnotetext{
${ }^{1}$ Ramyar Aliramayee, Former Master Student, Department of Watershed Management Engineering, Faculty of Natural Resources, Tarbiat Modares University, Noor, IRAN; Abdulvahed Khaledi Darvishan, (corresponding author: a.khaledi@modares.ac.ir), Department of Watershed Management Engineering, Faculty of Natural Resources, Tarbiat Modares University, Noor, IRAN. Mahmood Arabkhedri, Soil Conservation and Watershed Management Research Institute, Agriculture Research, Education and Extension Organization, Tehran, IRAN.

Notes: The authors declare that they have no conflicts of interest. Authorship Form signed online.
} 
soil erosion is one of the major hydrological hazards in Iran (Sadeghi et al., 2013). Soil erosion depends on many parameters such as soil and topographic condition (e.g. antecedent soil moisture content, slope gradient and aspect) and rainfall characteristics (e.g. rainfall intensity and duration) (Arnaez, 2007; Assouline and Ben-Hur, 2006; El Kateb, 2013; Huang 2013). Study the factors that affect soil erosion is essential for soil and water conservation planning (Khaledi Darvishan et al., 2017; Spalevic et al., 2015, 2017a, 2017b). Many researches have been investigated the different aspects of soil erosion and some of them have been conducted to study the effect of rainfall intensity and/or slope gradient in different land uses on soil erosion. Some studies have been also investigated the effects of surface seal induced variations on infiltration, runoff and erosion processes (Bradford et al., 1987; Mualem et al., 1993; Foley and Silburn 2002; Assouline, 2004; Liu, 2015; Khaledi Darvishan et al, 2015).

Few studies have been investigated soil erosion in different rainfall intensity and slope gradients in rainfed lands. Rainfed lands accounts for about $82 \%$ of the world's total cropland (FAOSTAT 2005). Rainfed lands usually carry out in semiarid condition which no irrigation water is available. The area of rainfed lands in Iran is about 10 million hectares (Siadat 1998) located in the areas which its ecosystem is very sensitive to weather uncertainties and climate change. Vegetation cover change leads to the changes of hydrologic response, soil erosion and sediment dynamics characteristics (Kavian et al., 2018; Nikolic et al., 2018). The effect of vegetation cover change is more important in semiarid regions because of the sensitivity of vegetation cover and relative higher intensity and shorter duration of rainfalls in these areas.

One of the main consequences of soil erosion is the loss of soil fertility and the depletion of nutrients such as Nitrogen, Phosphorus and Potassium (Kauffman et al., 1993; Miller, 1995). These three elements are the most important elements of plant nutrition (Hanson, 1967).

The topsoil usually contains more organic matter, which improves infiltration and increases water holding capacity (Pimental et al., 2004). It is the first part of soil that exposed to erosion. The most effective factors in soil permeability are organic materials that play an important role in soil water retaining and soil permeability. Splash erosion which depends on rain drop size distribution and velocity, is an important process (Khaledi Darvishan et al., 2014) and can significantly affect the soil surface. In general, the most sensitive time to erosion in arable land is the periods in which the plant does not exist and when the rainfalls are erosive (Walter and Dwight, 1978). Therefore, the rainfed lands in the plowing stage before cultivating until the plant is still insufficient to protect soil surface (spring and summer) are in the most sensitive condition. The rainfalls in these two seasons have also high intensity and short duration, so that the highest amount of soil and nutrient loss can occur.

Many of previous studies have been carried out to determine the effects of slope gradient and rainfall intensity on hydrological response variables such as infiltration and runoff (Peoson 1984, Romkens et al 2002, Grander and Gerard 
2003, Marquez et al 2005, Sadeghi et al 2013, Huang et. al, 2013, El Kateb et. al, 2013, Khaledi Darvishan 2015, Liu et al 2015) and sediment concentration and soil loss (Fox and Brayan 1999, Poulenard et. al 2001, Grander and Gerard 2003, Assouline et.al 2006, Arnaez et. al 2007, Romkens et. al 2002, Elkateb et. al 2013, Zhao et.al 2015, Liu et. al 2015). The results of previous studies generally showed that infiltration and runoff were significantly affected by slopes and rainfall intensities. Because of the importance of rainfed lands especially in the northeast of Iran, despite the results of previous researches, it is still very important to quantify the effects of slope gradient and rainfall intensity on hydrological response as well as soil nutrient loss in these lands.

In rainfed lands located in Golestan province, heavy rains usually occur in summer with consequent high flood events. Therefore, it's very important to study soil erosion and its parameters in rainfed lands of Iran. The present study has been conducted to know the individual and interaction effects of rainfall intensity and slope gradient on soil and nutrient losses in rainfed lands in northeast of Iran.

The results of the present study can be used to distinguish the critical of slope gradient and rainfall intensity in case of their effects on hydrological response in rainfed lands.

\section{MATERIALS AND METHODS}

\section{Study area}

The field experiments were conducted using a small simulator (Kamphorst, 1978) in Pishkamar ( $\left.37^{\circ} 31^{\prime} \mathrm{N}-5^{\circ} 35^{\prime} \mathrm{E}\right)$ which is located in Golestan province, NE Iran (Figure 1). Pishkamar has an average elevation around $1000 \mathrm{~m}$ above sea level with mean annual precipitation of $592.8 \mathrm{~mm}$ with maximum and minimum monthly amounts in January $(80.5 \mathrm{~mm})$ and July (28.4 $\mathrm{mm}$ ), respectively. The maximum and minimum seasonal precipitation is commonly occurring in winter and summer, respectively. The major soil of Pishkamar is silty-loam (26\% Clay, $66 \%$ silt and $8 \%$ sand) with $44 \%$ porosity. Most of the slopes are in the range between 6 and 25\% gradient. The major land uses in the study area are rangeland, forest, rainfed and irrigated lands.

\section{Layout of experiments}

The studied soil covered by erosion control blanket to protect soil from direct hitting of rain drops and splash erosion occurring and sprinkled 5 liter of water for each $0.5 \times 0.5 \mathrm{~m}$ using a handy sprinkler to soaking soil until $5 \mathrm{~cm}$ depth after $24 \mathrm{~h}$, in order to achieve the same antecedent soil moisture content equal to field capacity in all the study plots. Three slope gradients of 6,12 and $25 \%$ and four rainfall intensities of 30,60, 80 and $120 \mathrm{~mm} \mathrm{~h}^{-1}$ were applied. The rainfall duration was $15 \mathrm{~min}$ for all experiments because of limited volume of water reservoir of rainfall simulator. In the present study the Intensity-DurationFrequency curves of the nearest synoptic weather station of Kalaleh (shown in Figure 1 as a red triangle) were used to determine the relationship between rainfall 
intensity, duration and return period in the study area. In this regard the return period of 15-20 years for the given rainfall intensities was considered.
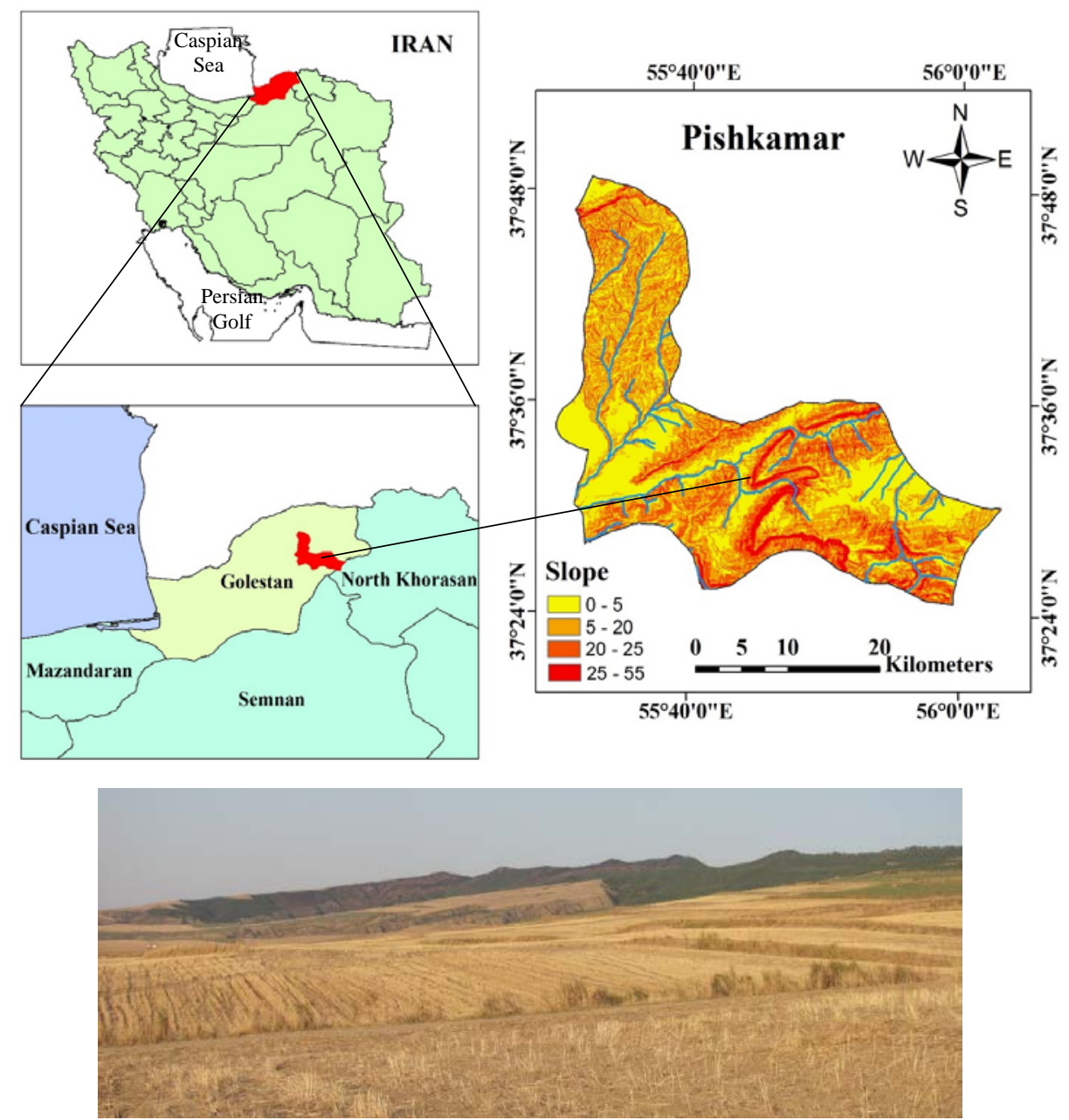

Figure 1. Location and general landscape of the study area

The selected duration of 15 min was corresponding with the high rainfall intensities, so that it considered for all given intensities of 30, 60, 80 and $120 \mathrm{~mm}$ $\mathrm{h}^{-1}$. The Sprinkling on jute bags to achieve antecedent soil moisture content equal to field capacity and a Kamphorst rainfall simulator and clinometer are shown in Figure 2.

\section{Data collection and analysis}

During rainfall simulation in each treatment, runoff samples were collected in special bottles for immediately transport to laboratory to avoid preventing bacteria's effects on soil nutrients (carter, 1993). Measurable runoff was recorded for each experiment and then the infiltration rate was calculated as the difference between the amount of rainfall on the plot area and the runoff output at the same 
time. The sediment concentration was measured using decantation procedure, oven dried at $105^{\circ} \mathrm{C}$ for $24 \mathrm{~h}$ (Khaledi Darvishan el al., 2016) (Figure 2).

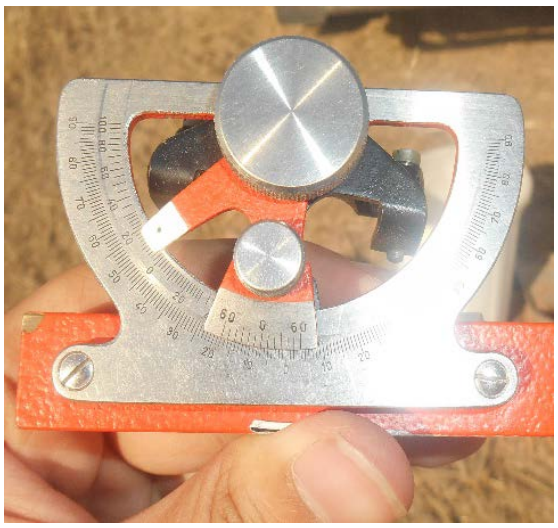

A

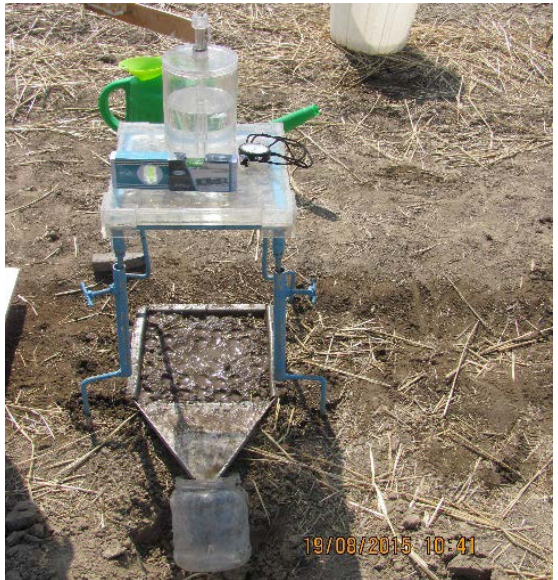

C

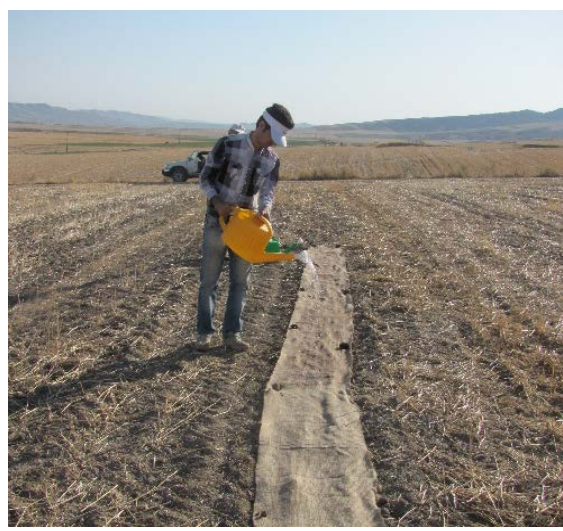

B

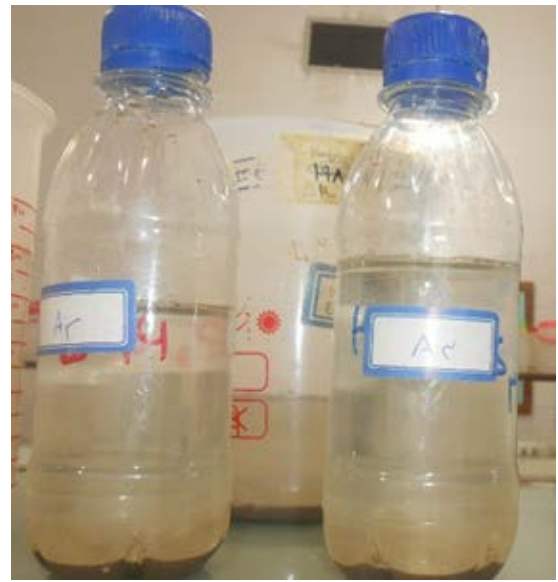

$\mathrm{D}$

Figure 2. Find intended slope with clinometer (A) Sprinkling on jute bags to achieve antecedent soil moisture content equal to field capacity (B), rainfall simulation and collecting runoff $(\mathrm{C}$ and $\mathrm{D})$

In the end of measuring samples sent to the laboratory and other variables such as soil nutrients in original soil, sediment samples and runoff samples were measured. The methods that used for measuring Nitrogen, Phosphorus and potassium in laboratory were Kjeldahl, Olsen and Photometry respectively (Bremner, 1960; Watanabe and Olsen, 1965; Reitman and Frankel, 1957). As runoff and sediment were not enough to determine soil nutrients in some samples, samples were mixed together.

\section{Statistical analysis}

The experimental design of spilt plots and factorial experiments with four slope gradient-aspect conditions (6\%-north, 12\%-north, 25\%-north and 25\%- 
south) and four rainfall intensities (33, 64, 80 and $110 \mathrm{~mm} \mathrm{~h}^{-1}$ ) were performed as statistical tests. The normality test was done for all variables of infiltration, runoff and soil and nutrient loss. The un-normal variables were transformed to logarithmic form to achieve normality distribution, because parametric tests on normal data seems to be more powerful to detect the differences than the nonparametric tests on non-normal data (Townend, 2002). The analysis of variance (ANOVA) with considering the split plots design (Bihamta and Zare Chahouki, 2011) was performed to describe the individual and interaction effects of rainfall intensity and slope gradient on the study variables including infiltration, runoff, soil and nutrient loss. The statistical analysis was performed using SPSS 21 software.

\section{Study soils}

\section{RESULTS AND DISCUSSION}

The results of physical and chemical characteristics of soil samples have been shown in Table 1.

Table 1 Physical \& Chemical properties of the studied soil and Amount of organic matter and bulk density in various studied slopes

\begin{tabular}{|c|c|c|c|c|c|}
\hline $\begin{array}{l}\text { Physical } \\
\text { properties }\end{array}$ & Unit & Amount & Chemical properties & Unit & Amount \\
\hline Bulk density & $\mathrm{g} \mathrm{cm}^{-3}$ & 1.50 & $\mathrm{pH}$ & --- & 8.54 \\
\hline Density & $\mathrm{g} \mathrm{cm}^{-3}$ & 2.68 & EC & ds. $m^{-1}$ & 1.38 \\
\hline Porosity & $\%$ & 44 & $\mathrm{CaSO} 4$ & Percent & 0.005 \\
\hline Clay & $\%$ & 26 & SAR & - & 0.48 \\
\hline Silt & $\%$ & 66 & Lime & Percent & 30.97 \\
\hline Sand & $\%$ & 8 & Carbonate & \multirow{8}{*}{ Meq..$^{-1}$} & 00 \\
\hline Soil texture & --- & silty-loam & Bicarbonate & & 5 \\
\hline \multirow{2}{*}{ Soil sample } & \multirow{2}{*}{ Bulk density $\left(\mathrm{g} \mathrm{cm}^{-3}\right)$} & \multirow{2}{*}{$\begin{array}{c}\text { Organic } \\
\text { matter (\%) }\end{array}$} & Chlorine & & 4.5 \\
\hline & & & Sulfate & & 7.7 \\
\hline Slope 6\%-North & 1.454 & 1.017 & Calcium solution & & 10.0 \\
\hline Slope $12 \%-N o r t h$ & 1.239 & 1.059 & Magnesium solution & & 5.2 \\
\hline Slope 25\%-North & 1.369 & 1.073 & Sodium solution & & 1.9 \\
\hline Slope 25\%-South & 1.391 & 0.975 & Potassium solution & & 0.15 \\
\hline
\end{tabular}

Because of the more importance and variability of organic matter (OM \%) in various slope gradient and aspects, the soil was sampled in each studied slope separately and then the OM were measured and shown in Table 3.

\section{Infiltration and runoff}

The results of statistical analysis to investigate the individual and interaction effects of rainfall intensity and slope gradient on infiltration and runoff variables are shown in Figures 3 and 4 and Table 2. As shown in Figure 3, in rainfall intensity of $33 \mathrm{~mm} \mathrm{~h}^{-1}$ the rainfall has not intense enough to generate measurable runoff in all studied slopes. The effects of slope gradient and rainfall 
intensity on mean infiltration coefficient and mean runoff coefficient were significant $(\mathrm{P} \leq 0.01)$. The interaction effect of slope gradient and rainfall intensity on mean infiltration coefficient and mean runoff coefficient were also significant in $\mathrm{P} \leq 0.01$ and $\mathrm{P} \leq 0.05$, respectively (Table 2 ).

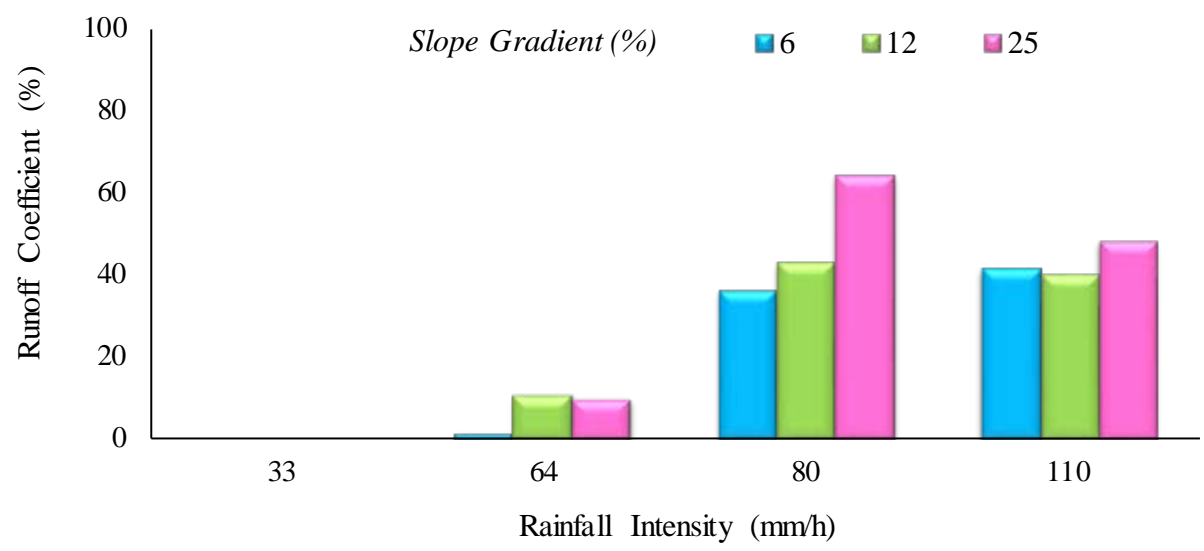

Figure 3. Effect of rainfall intensity and slope gradient on runoff coefficient

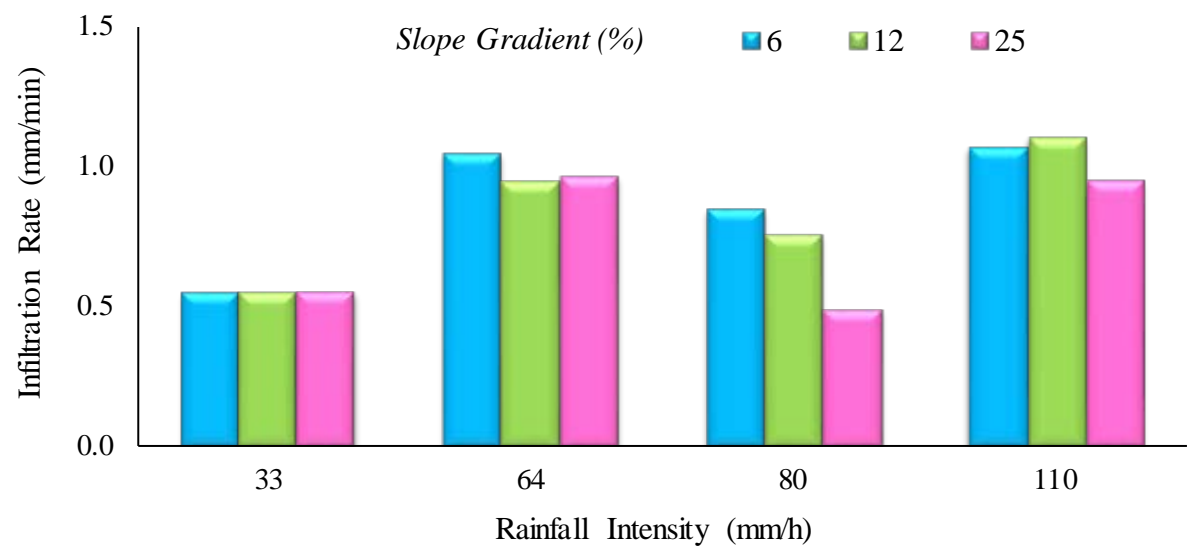

Figure 4. Effect of rainfall intensity and slope gradient on mean infiltration rate

After realizing that the effect of rainfall intensity and slope gradient on mean infiltration coefficient rate and runoff coefficient is significant, Determination of significant differences between studied rainfall intensities and slope gradients using post hoc analysis (Duncan test) was carried out (Table 3).

The purpose of using post hoc analysis was to determine significant changes between the levels of treatments (slope gradient and rainfall intensity) which leads to understand the turning points in hydrological response in the study conditions. 
Table 2. The results of the effects of slope gradient and rainfall intensity on infiltration and runoff variables

\begin{tabular}{|c|c|c|c|c|c|c|}
\hline Dependent Variable & Source & $\begin{array}{l}\text { Type III Sum of } \\
\text { Squares }\end{array}$ & df & $\begin{array}{l}\text { Mean } \\
\text { Square }\end{array}$ & $\mathrm{F}$ & Sig. \\
\hline \multirow{3}{*}{$\begin{array}{c}\text { Infiltration rate } \\
\text { (\%) }\end{array}$} & Slope & 0.178 & 2 & 0.089 & 7.237 & 0.002 \\
\hline & Rainfall intensity & 1.974 & 3 & 0.658 & 53.435 & 0.000 \\
\hline & $\begin{array}{c}\text { Slope } \times \text { Rainfall } \\
\text { intensity }\end{array}$ & 0.193 & 6 & 0.032 & 2.615 & 0.033 \\
\hline \multirow{3}{*}{$\begin{array}{l}\text { Depth of runoff } \\
\text { (mm) }\end{array}$} & Slope & 39.497 & 2 & 19.749 & 7.174 & 0.002 \\
\hline & Rainfall intensity & 1262.405 & 3 & 420.802 & 152.866 & 0.000 \\
\hline & $\begin{array}{c}\text { Slope } \times \text { Rainfall } \\
\text { intensity }\end{array}$ & 42.891 & 6 & 7.184 & 2.597 & 0.034 \\
\hline \multirow{3}{*}{$\begin{array}{c}\text { Mean runoff } \\
\text { coefficient } \\
\text { (\%) }\end{array}$} & Slope & 1.082 & 2 & 0.541 & 11.183 & 0.000 \\
\hline & Rainfall intensity & 2.358 & 3 & 0.795 & 16.432 & 0.000 \\
\hline & $\begin{array}{c}\text { Slope } \times \text { Rainfall } \\
\text { intensity }\end{array}$ & 4.631 & 6 & 0.772 & 15.951 & 0.000 \\
\hline \multirow{3}{*}{$\begin{array}{c}\text { Soil loss } \\
\left(\mathrm{kg} \cdot \mathrm{h}^{-1}\right)\end{array}$} & Slope & 157.327 & 2 & 78.664 & 6.844 & 0.000 \\
\hline & Rainfall intensity & 645.511 & 3 & 215.170 & 18.721 & 0.000 \\
\hline & $\begin{array}{c}\text { Slope } \times \text { Rainfall } \\
\text { intensity }\end{array}$ & 141.750 & 6 & 23.625 & 2.056 & 0.083 \\
\hline \multirow{3}{*}{$\begin{array}{c}\text { Sediment } \\
\text { concentration } \\
\left(\mathrm{g} . \mathrm{l}^{-1}\right)\end{array}$} & Slope & 225.742 & 2 & 112.871 & 5.828 & 0.006 \\
\hline & Rainfall intensity & 895.727 & 3 & 298.576 & 15.416 & 0.000 \\
\hline & $\begin{array}{c}\text { Slope } \times \text { Rainfall } \\
\text { intensity }\end{array}$ & 142.466 & 6 & 23.744 & 1.226 & 0.316 \\
\hline
\end{tabular}

As shows in Table 3, mainly two groups have been created, slope gradient 6 and 12\% located in one individual group and 25\% separated in another group. In case of rainfall intensity, 33 and $64 \mathrm{~mm} \mathrm{~h}^{-1}$ were in one group, while 80 and $110 \mathrm{~mm} \mathrm{~h}^{-1}$ were in another group. It means that there are significant changes in hydrological response between slope gradients of 12 and $25 \%$ as well as between rainfall intensities of 64 and $80 \mathrm{~mm} \mathrm{~h}^{-1}$. Therefore, it can be concluded that the critical slope gradient and rainfall intensity are located somewhere between 12$25 \%$ and $64-80 \mathrm{~mm} \mathrm{~h}^{-1}$, respectively.

These results show that mean infiltration rate intensity of 64 and 100 have not significant difference and they located in one subset and we have three subsets. So we have significant difference between 33, 80 and $64 \_110 \mathrm{~mm} \mathrm{~h}^{-1}$ intensities.

The results showed that as rainfall intensity and slope gradient increased, the mean infiltration rate and mean runoff coefficient were also significantly increased $(\mathrm{p} \leq 0.01)$.

The results of post hoc analysis for rainfall intensity and slope gradient using Duncan test showed that, in case of the effects of rainfall intensity and slope gradient on infiltration and runoff, two turning points are distinguishable in studied conditions; one between rainfall intensities of 64 and $80 \mathrm{~mm} \mathrm{~h}^{-1}$ and another between slope gradient of 12 and $25 \%$. In other words, at the rainfall intensity more than about $70 \mathrm{~mm} \mathrm{~h}^{-1}$ and at the slope gradient more than about $18 \%$, the runoff and infiltration were significantly decreased and increased, 
respectively. This results emphasized on land use management via avoiding change from rangelands to rainfed lands especially when the slope is more than $18 \%$.

Table 3. Determination of significant differences between studied rainfall intensities and slope gradients using post hoc analysis (Duncan test)

\begin{tabular}{|c|c|c|c|}
\hline Source - Subsets & Subset 1 & Subset 2 & Subset 3 \\
\hline \multirow{10}{*}{$\begin{array}{l}\text { Rainfall intensity } \\
\qquad\left(\mathrm{mm} \mathrm{h}^{-1}\right)\end{array}$} & \multicolumn{3}{|c|}{ Mean infiltration rate (\%) } \\
\hline & 33 & 80 & 64,100 \\
\hline & \multicolumn{3}{|c|}{ Runoff (mm) } \\
\hline & 33,64 & 80 & 110 \\
\hline & \multicolumn{3}{|c|}{ Mean runoff coefficient (\%) } \\
\hline & 33,64 & 80,110 & - \\
\hline & \multicolumn{3}{|c|}{ Sediment concentration $\left(\mathrm{g} \mathrm{l}^{-1}\right)$} \\
\hline & 33 & $64,80,11$ & - \\
\hline & \multicolumn{3}{|c|}{ Soil loss $\left(\mathrm{kg} \mathrm{h}^{-1}\right)$} \\
\hline & 33,64 & 80,110 & - \\
\hline \multirow{10}{*}{$\begin{array}{l}\text { Slope } \\
(\%)\end{array}$} & \multicolumn{3}{|c|}{ Mean infiltration rate (\%) } \\
\hline & 25 & 6,12 & - \\
\hline & \multicolumn{3}{|c|}{ Runoff (mm) } \\
\hline & 6,12 & 25 & - \\
\hline & \multicolumn{3}{|c|}{ Mean runoff coefficient (\%) } \\
\hline & 12,25 & 6 & - \\
\hline & \multicolumn{3}{|c|}{ Sediment concentration $\left(\mathrm{g}^{-1}\right)$} \\
\hline & 6 & 12,25 & - \\
\hline & \multicolumn{3}{|c|}{ Soil loss $\left(\mathrm{kg} \mathrm{h}^{-1}\right)$} \\
\hline & 6,12 & 25 & - \\
\hline
\end{tabular}

\section{Sediment concentration and soil loss}

Sediment concentration and soil loss were affected by both slope gradient and rainfall intensity as well as by their interactions. The results indicated that sediment concentration increased with increasing rainfall intensity in all slope gradients. The effect of rainfall intensity and slope gradient on sediment concentration and soil loss was significant. The results of subgrouping with Duncan test showed that between the rainfall intensities of $33-64 \mathrm{~mm} \mathrm{~h}^{-1}$ and between the slope gradients of $6-12 \%$, the sediment concentration was significantly changed. In case of soil loss, the significant change was happened between the rainfall intensities of $64-80 \mathrm{~mm} \mathrm{~h}^{-1}$ and the slope gradients of 12$25 \%$, respectively. In other words, with assuming a linear relationship changes, at a given plot scale the critical condition in sediment concentration (detach and arrival to transport agent) was the rainfall intensity of around $50 \mathrm{~mm} \mathrm{~h}^{-1}$ and slope gradient of around $9 \%$ but for soil loss (soil transport), it was around 72 $\mathrm{mm} \mathrm{h}^{-1}$ and $18 \%$, respectively. 


\section{Soil nutrients (NPK)}

The results of soil nutrients including Nitrogen, Phosphorus and Potassium in two slope gradients of 6 and $25 \%$ are shown in Table 4. The differences between soil nutrients $\mathrm{N}, \mathrm{P}$ and $\mathrm{K}$ in two extreme slope gradients (6 and 25\%) are not considerable, it means that there is no need to sample and measure soil nutrients in slope gradient of $12 \%$.

Since there were no considerable differences between $\mathrm{N}, \mathrm{P}$ and $\mathrm{K}$ in two extreme studied slope gradients of 6\%-North and 25\%-North, it can simply reveal that the effect of slope gradient in the given range in the study area on $\mathrm{N}, \mathrm{P}$ and $\mathrm{K}$ is ignorable. But in case of the effect of slope aspect on studied variables, the soil sampling in the slope gradient of $25 \%$-South was also done and nutrients were measured and compared with those in the slope gradient of $25 \%$-North and the results are shown in Table 4.

Table 4. Comparison between the results of soil nutrients and organic matter in two slope gradients of 6\%-North and 25\%-North and 25\%-South

\begin{tabular}{|c|c|c|c|c|c|c|c|}
\hline \multicolumn{2}{|c|}{$\begin{array}{c}\text { Organic matter and soil nutrient of slope 25\%- } \\
\text { North }\end{array}$} & \multicolumn{5}{|c|}{ Organic matter and soil nutrient of slope 6\%- } \\
North
\end{tabular}

The results presented in Table 5 indicated that Nitrate, Ammonium and Phosphorus contents of runoff in the experiments under rainfall intensity of 80 $\mathrm{mm} \mathrm{h}^{-1}$ in the slope gradient of $12 \%$ in North aspect had the significant difference with those under rainfall intensity of $110 \mathrm{~mm} \mathrm{~h}^{-1}$ in the slope gradient of $25 \%$ in South aspect, while in case of Potassium the differences were not significant. These results were in agreement with previous studies such as Alberts (1981).

Because of non-significant changes in N, A and P in the runoff of the given extreme experiments (lowest slope gradient and rainfall intensity against highest ones-Table 4), the measurements were not carried out for other samples, so that only the results of $12 \%$-North and $25 \%$-South slopes are presented in Tables 5 and 6.

Table 5. Comparison between the results of nutrients and organic matter in the runoff of the plots located in two slope gradients of 12\%-North and 25\%-South

\begin{tabular}{|c|c|c|c|c|c|c|}
\hline \multirow{2}{*}{ Slope } & \multirow{2}{*}{$\begin{array}{c}\text { Rainfall } \\
\text { intensity }\end{array}$} & \multirow{2}{*}{$\begin{array}{c}\text { Rainfall } \\
\text { depth }\end{array}$} & \multicolumn{4}{|c|}{ Concentration of nutrients in runoff } \\
\cline { 5 - 7 } & $\left(\mathrm{mm} \mathrm{h}^{-1}\right)$ & $(\mathrm{mm})$ & Nitrate & $\begin{array}{c}\text { Ammonium } \\
\text { ions }\end{array}$ & $\begin{array}{c}\text { Phosphorus } \\
\text { ions }\end{array}$ & $\begin{array}{c}\text { Potassium } \\
\text { ions }\end{array}$ \\
\hline 12\%-North & 80 & 20 & 0.89 & 0.14 & 0.13 & 4.56 \\
\hline $25 \%$-South & 110 & 27.5 & 0.00 & 0.36 & 0.02 & 2.63 \\
\hline
\end{tabular}


Table 6. Comparison between the results of nutrients and organic matter in the soils and sediments in the plots located in two slope gradients of $12 \%$-North and $25 \%$-South

\begin{tabular}{|c|c|c|c|c|c|c|c|c|c|c|}
\hline \multirow[b]{2}{*}{$\begin{array}{l}\frac{\tilde{0}}{\omega} \\
\frac{1}{2}\end{array}$} & \multirow[b]{2}{*}{ 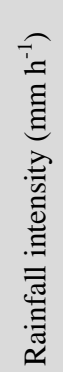 } & \multirow[b]{2}{*}{ 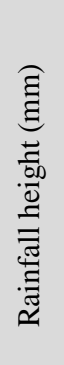 } & \multicolumn{4}{|c|}{ Soil } & \multicolumn{4}{|c|}{ Sediment } \\
\hline & & & 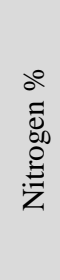 & 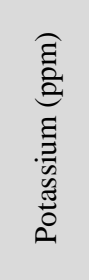 & 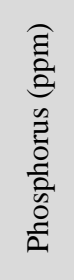 & 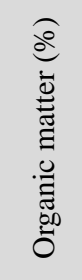 & 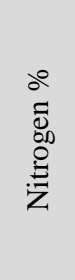 & 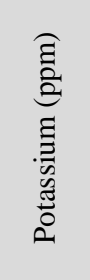 & 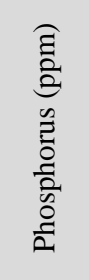 & 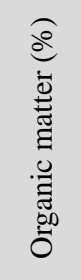 \\
\hline $\begin{array}{l}\overline{0} \\
\text { z } \\
0\end{array}$ & 80 & 20 & 0.1 & 206.1 & 3.59 & 1.059 & 0.07 & 344.7 & 12.47 & 0.975 \\
\hline ప & 110 & 27.5 & 0.1 & 155.4 & 2.42 & 0.975 & 0.13 & 233.5 & 6.35 & 0.953 \\
\hline
\end{tabular}

The comparison between the results of nutrients and organic matter in the soils and sediments in the plots located in two slope gradients of $12 \%$-North and 25\%-South have been shown in Table 6.

Although as shows in Table 6, the differences between Nitrogen and also organic matter in the soil (before experiment) and the sediment at the plot outlet was not considerable, in higher slope (25\%) the amount of Nitrogen in sediment was more than soil, while the amount of organic matter in sediment samples was lower than the original soil in both $12 \%$ and $25 \%$ slopes.

Since the amount of organic matter is highly related with the amount of organic Carbon in the soil, the results showed that Nitrogen is carried out with sediment a little bit more than Carbon. It can be one of the main sources of increasing $\mathrm{C} / \mathrm{N}$ ratio in rainfed lands and one of the main reasons for burning straws after harvest by the local farmers. The results also indicated that the amount of Phosphorus and Potassium in original soil were clearly lower than those in sediment samples.

\section{CONCLUSION}

The main objective of the present study was to investigate the individual and interaction effects of slope and rainfall intensity on infiltration, runoff, soil and nutrient loss in rainfed lands in Golestan Province, northeast of Iran. According to the results: 
-The individual effects of slope gradient and rainfall intensity on infiltration and runoff were significant.

-The interaction of the slope gradient and rainfall intensity on infiltration and runoff was significant.

-The individual effect of rainfall intensity and its interaction with the rainfall intensity on sediment concentration were significant.

-The effect of slope and rainfall intensity on soil loss was significant individually, but their interaction on soil loss was not significant.

-The amounts of OM in original soil of the studied slopes was more than the sediment in all studied slope gradients.

- The amounts of $\mathrm{N}$ in original soil of the studied slopes was less than the sediment in higher slope gradient.

-The amount of Phosphorus and Potassium in original soil were clearly lower than those in sediment samples.

\section{ACKNOWLEDGMENT}

The authors would like to thank to Engr. Reza Bayat for his ongoing assistance to coordinate cooperation in field works. The laboratory investigations have been conducted in laboratory of Soil Conservation and Watershed Management Research Institute (SCWMRI) of Iran where have been partly supported as part of research project code: 04-29-29-95117. The support provided by the SCWMRI is gratefully acknowledged.

\section{REFERENCES}

Alberts, E. E., Neibling, W. H., Moldenhauer, W. C. (1981) Transport of sediment nitrogen and phosphorus in runoff through cornstalk residue strips. Soil Science Society of America Journal, 45(6): 1177-1184.

Arnaez, J., Lasanta, T., Ruiz-Flaño, P., Ortigosa, L. (2007) Factors affecting runoff and erosion under simulated rainfall in Mediterranean vineyards. Soil and Tillage Research, 93(2): 324-334.

Assouline, S. and Ben-Hur, M., (2006) Effects of Rainfall Intensity and Slope Gradient on the Dynamics of Interrill Erosion during Soil Surface Sealing. Catena, 66: 211220.

Assouline, S., (2004) Rainfall-induced soil surface sealing. Vadose Zone J. 3 (2), 570591.

Bremner, J. M. (1960). Determination of nitrogen in soil by the Kjeldahl method. The Journal of Agricultural Science, 55(1), 11-33.

Bihamta, M.R., and Zare Chahouki, M.A. (2011) Statistics principles in natural resources, 2nd edn., Tehran University Press, Iran, 300 pp. (In Persian)

Bradford, J.M., Ferris, J.E., Remley, P.A., (1987) Interrill soil erosion processes: I. Effect of surface sealing on infiltration, runoff, and soil splash detachment. Soil Sci. Soc. Am. J. 51(6): 1566-1571.

Chalise, D.; Kumar, L.; Spalevic, V.; Skataric, G. (2019) Estimation of Sediment Yield and Maximum Outflow Using the IntErO Model in the Sarada River Basin of Nepal. Water, 11: 952. 
El Kateb, H., Zhang, H., Zhang, P., Mosandl, R. (2013) Soil erosion and surface runoff on different vegetation covers and slope gradients: a field experiment in Southern Shaanxi Province, China. Catena, 105: 1-10.

FAOSTAT, (2005) Food and Agriculture Organization (FAO), Rome, http://faostat.fao.org.

(http://www.fao.org/search/en/?cx=018170620143701104933\%3Aqq82jsfba7w\&q =FAOSTAT\%2C+\%282005\%29+Food+and+Agriculture+Organization+\%28FAO \%29\%2C+Rome\&cof=FORID\%3A9\&siteurl=www.fao.org\%2Ffaostat\%2Fen\%2 F\%23home\&ref=\&ss=2499j3126149j4)

Foley, J.L., Silburn, D.M., (2002) Hydraulic properties of rain impact surface seals on three clay soils - influence of raindrop impact frequency and rainfall intensity during steady state. Soil Res. 40(7): 1069-1083.

Fox, D. M., Bryan, R. B. (2000) The relationship of soil loss by interrill erosion to slope gradient. Catena, 38(3): 211-222.

Gardner, R. A. M., Gerrard, A. J. (2003) Runoff and soil erosion on cultivated rainfed terraces in the Middle Hills of Nepal. Applied Geography, 23(1): 23-45.

Huang, J., Wu, P., Zhao, X. (2013) Effects of rainfall intensity, underlying surface and slope gradient on soil infiltration under simulated rainfall experiments. Catena, 104: 93-102.

Kamphorst, A., (1987) A small rainfall simulator for the determination of soil erodibility. Netherlands Journal of Agricultural Science, 35: 407-415. (http://library.wur.nl/WebQuery/wurpubs/4282)

Kavian, A., Mohammadi, M., Gholami, L., and Rodrigo-Comino, J. (2018) Assessment of the spatiotemporal effects of land use changes on runoff and nitrate loads in the Talar River. Water, 10(4), 445.

Khaledi Darvishan, A., K. Banasik, S.H.R. Sadeghi, L. Gholami and L. Hejduk. (2015) Effects of rain intensity and initial soil moisture on hydrological responses in laboratory conditions. International Agrophysics, 29(2): 165-173.

Khaledi Darvishan A., Behzadfar M., Spalevic V., Kalonde P., Ouallali A., Mouatassime E. S., (2017) Calculation of sediment yield in the S2-1 watershed of the Shirindareh river basin, Iran, Agriculture and Forestry, 63 (3): 23-32.

Khaledi Darvishan, A., Homayounfar, V., and Sadeghi, S.H.R., (2016) The impact of standard preparation practice on the runoff and soil erosion rates under laboratory conditions. Solid Earth, 7: 1293-1302.

Koulouri, M. and Giourga, C., (2007) Land abandonment and slope gradient as key factors of soil erosion in Mediterranean terraced lands. Catena, 69(3): 274-281.

Liu, D., She, D., Shao, G., Chen, D., (2015) Rainfall intensity and slope gradient effects on sediment losses and splash from a saline-sodic soil under coastal reclamation. CATENA, 128: 54-62.

Marqués, M. J., Jiménez, L., Pérez-Rodríguez, R., GarcÍa-Ormaechea, S., Bienes, R. (2005) Reducing water erosion in a gypsic soil by combined use of organic amendment and shrub revegetation. Land Degradation \& Development, 16(4): 339-350.

Mualem, Y., Assouline, S., Eltahan, D., (1993) Effect of rainfall-induced soil seals on soil water regime: wetting processes. Water Resour. Res. 29(6): 1651-1659.

Nikolic, G., Spalevic, V., Curovic, M., Khaledi Darvishan, A., Skataric, G., Pajic, M., Kavian, A., \& Tanaskovik, V. (2018) Variability of Soil Erosion Intensity Due to Vegetation Cover Changes: Case Study of Orahovacka Rijeka, Montenegro. Notulae Botanicae Horti Agrobotanici Cluj-Napoca, 47(1), 237-248. 
Poesen, J., (1984) The influence of slope angle on infiltration rate and Hortonian overland flow. Zeitschrift für Geomorpholgie, Supplement Band, 49: 117-131.

Poulenard, J., Podwojewski, P., Janeau, J. L., Collinet, J. (2001) Runoff and soil erosion under rainfall simulation of Andisols from the Ecuadorian Páramo: effect of tillage and burning. Catena, 45(3): 185-207.

Römkens, M., Helming, K., Prasad, S., (2002) Soil erosion under different rainfall intensities, surface roughness, and soil water regimes. Catena, 46(2): 103-123.

Reitman, S., \& Frankel, S. (1957). A colorimetric method for the determination of serum glutamic oxalacetic and glutamic pyruvic transaminases. American journal of clinical pathology, 28(1), 56-63.

Sadeghi, S. H. R., Gholami, L., Khaledi Darvishan, A. V. (2013) Suitability of MUSLT for storm sediment yield prediction in Chehelgazi watershed, Iran. Hydrological Sciences Journal, 58(4), 892-897.

Sadeghi SH, Seghaleh MB, Rangavar AS. (2013) Plot sizes dependency of runoff and sediment yield estimates from a small watershed. Catena. Mar 31(102): 55-61.

Siadat, H., (1998) Iranian Agriculture and Salinity. Soil \& Water Research Institute of Iran, $6 \mathrm{P}$.

Spalevic, V., Curovic, M., Barovic, G., Vujacic, D., Tunguz, V. and Djurovic, N. (2015) Soil erosion in the river basin of Provala, Montenegro. Agriculture and Forestry, 61(4): 133-143.

Spalevic, V., Lakicevic, M., Radanovic, D., Billi, P., Barovic, G., Vujacic, D., Sestras, P. and Khaledi Darvishan, A. (2017) Ecological-economic (Eco-Eco) modelling in the River Basins of Mountainous Regions: Impact of land cover changes on sediment yield in the Velicka Rijeka, Montenegro. Notulae Botanicae Horti Agrobotanici Cluj-Napoca, 45(2): 602-610.

Spalevic, V., Radanovic, D., Skataric, G., Billi. P., Barovic, G., Curovic, M., Sestras, P., and Khaledi Darvishan A. (2017) Ecological-economic (eco-eco) modelling in the mountainous river basins: Impact of land cover changes on soil erosion. Agriculture and Forestry, 63 (4): 9-25.

Townend, J. (2002) Practical statistics for environmental and biological scientists. Chichester, John Wiley and Sons, New York, USA.

Watanabe, F. S., \& Olsen, S. R. (1965). Test of an ascorbic acid method for determining phosphorus in water and NaHCO3 extracts from soil 1. Soil Science Society of America Journal, 29(6), 677-678.

Zhao, X., Huang, J., Gao, X., Wu, P., Wang, J. (2014) Runoff features of pasture and crop slopes at different rainfall intensities, antecedent moisture contents and gradients on the Chinese Loess Plateau: A solution of rainfall simulation experiments. Catena, 119: 90-96. 